\title{
African dust is an unlikely source of Aspergillus sydowii, the causative agent of sea fan disease
}

\author{
Krystal L. Rypien* \\ Department of Ecology \& Evolutionary Biology, Dale R. Corson Hall, Cornell University, Ithaca, New York 14853, USA \\ Present address: Scripps Institution of Oceanography, Marine Biology Research Division, 9500 Gilman Drive MC 0202 , \\ La Jolla, California 92093, USA
}

\begin{abstract}
Infection of sea fans by the fungal pathogen Aspergillus sydowii is one of the most widespread coral diseases in the Caribbean. The source of this normally terrestrial fungus in marine ecosystems is perplexing, but of interest to coral conservationists, since tracking sources of pathogens provides one of the few avenues to limit pathogen spread. Hypothesized inputs of $A$. sydowii include terrestrial deposits, marine sources, and African dust. Windborne dust from Africa amounts to nearly $1 \times 10^{9} \mathrm{t} \mathrm{yr}^{-1}$, much of which is deposited over the Caribbean region. Several studies have examined the microbiota of African dust and detected the presence of Aspergillus spp., although identifications were only to the genus level. I used specific culture conditions to determine whether this coral pathogen is present in 4 samples of airborne dust from the Caribbean and Africa, and 3 sediment samples from Africa and the Cape Verde Islands (eastern Atlantic). A diversity of fungi were found, including 7 species of Aspergillus and related taxa. However, none of the samples contained $A$. sydowii. The lack of $A$. sydowii in airborne dust and sediment samples suggests that African dust is an unlikely source of the marine pathogen A. sydowii. Given the high richness of fungi observed, even under selective growth conditions, identification of potential pathogens to the species level is critical.
\end{abstract}

KEY WORDS: Coral disease · Aspergillosis · African dust · Sahara · Long-distance transport Sea fan disease

Resale or republication not permitted without written consent of the publisher

\section{INTRODUCTION}

Coral reefs are an ecosystem increasingly suffering the synergistic effects of a variety of stressors, including temperature (Hoegh-Guldberg 1999, Harvell et al. 2002), over-fishing (Hughes 1994), eutrophication (Fabricius 2005), and disease (Harvell et al. 1999, Harvell et al. 2007). The dramatic rise in coral disease since the 1970s (Harvell et al. 1999, Ward \& Lafferty 2004) is an area of considerable attention, as the causes behind the origin and spread of marine disease remain largely unknown. One factor that has been suggested to affect both the host and the pathogen is the input of wind-borne dust into Caribbean ecosystems (Shinn et al. 2000, Hayes et al. 2001, Garrison et al. 2003). The transport of dust from Africa to the Atlantic and Caribbean via trade winds has long been known by mariners (Gorbushina et al. 2007), and was first quantified in the late 1960s (Prospero 1968, Prospero et al. 1970). The amount of deposited dust is significant (ca. $1 \times 10^{9} \mathrm{t} \mathrm{yr}^{-1}$, D'Almeida 1986), and has been increasing steadily since the 1970s (Prospero \& Nees 1986, Prospero \& Lamb 2003). Recent climate modeling indicates that this increase in dust transport is due to a complex interaction of factors including sea surface temperature, global climate, regional meteorology, and surface materials (Moulin et al. 1997, Giannini et al. 2003, Prospero \& Lamb 2003, Moulin \& Chiapello 2006).

The pattern of increased African dust since the 1970s correlates strongly with the observed increase in disease outbreaks in Caribbean coral reef communities (Hayes et al. 2001). There are several hypothesized mechanisms by which an increase in African dust 
could result in an increase in coral disease. African dust is known to enhance deposition of nutrients to the Atlantic (Prospero et al. 1996, Arimoto et al. 2003), including iron, a limiting micronutrient in many marine systems (Jickells et al. 2005). Local enrichment of iron as a result of dust deposition may facilitate pathogen growth and spread (Hayes et al. 2001) or cause declines in coral health, since corals normally live in oligotrophic waters. Besides nutrients, African dust also deposits organic pollutants (van Dijk \& Guicherit 1999, Erel et al. 2006, Garrison et al. 2006), which may impair host immunity and lead to an increase in disease (Garrison et al. 2003, Garrison et al. 2006). Finally, African dust has been posited as a direct source of pathogenic organisms (Shinn et al. 2000). This hypothesis is consistent with numerous examples of long-distance dispersal (via wind) for a range of plant (Brown \& Hovmoller 2002, Aylor 2003) and animal (Venkatesh et al. 1975, Griffin et al. 2001a) pathogens.

For African dust deposits to be directly responsible for increasing pathogen inputs, microorganisms must be able to survive the conditions of the high atmosphere (temperature, UV) for about $1 \mathrm{wk}$, the average transit time for a dust cloud to move from Africa to the Caribbean (Prospero \& Nees 1986, Prospero et al. 2005). Despite the harsh conditions, a diversity of microorganisms have been detected in dust samples (Griffin et al. 2001b, Griffin et al. 2003, Shinn et al. 2003, Kellogg et al. 2004, Weir-Brush et al. 2004). The survival of these organisms is supported by models indicating that high altitude dust clouds can act as a highly efficient UV screen, protecting microorganisms in dust at lower altitudes (Herman et al. 1999). In addition, many of the microbes in dust clouds are pigmented (Garrison et al. 2003, Kellogg et al. 2004), which would offer additional protection from UV radiation.

African dust has been suggested as the source of Aspergillus sydowii, the pathogen responsible for aspergillosis in Caribbean gorgonian corals (Shinn et al. 2000). This disease was first observed in the 1980s (Garzón-Ferreira \& Zea 1992), and has caused high rates of mortality throughout the Caribbean (Nagelkerken et al. 1997, Kim \& Harvell 2004). This disease system has been a model for experimental studies as both the host and pathogen can be successfully grown in the laboratory. Despite the high prevalence and large effect of A. sydowii on gorgonian-dominated communities, the origin of the pathogen is unknown and hotly debated (Shinn et al. 2000). Some authors have suggested terrestrial sediments (Smith et al. 1996, Geiser et al. 1998) and marine sources (Roth et al. 1964, Steele 1967) as the most likely pathogen inputs. Shinn et al. (2000) cite the presence of the genus
Aspergillus in dust as evidence that African dust is the primary source of the coral pathogen A. sydowii.

Several previous studies examined the fungal biota of African dust (Griffin et al. 2001b, Griffin et al. 2003, Shinn et al. 2003, Kellogg et al. 2004, Weir-Brush et al. 2004), and, although several isolated Aspergillus spp. (Griffin et al. 2003, Shinn et al. 2003, Kellogg et al. 2004, Weir-Brush et al. 2004), none specifically documented the presence of $A$. sydowii. Given that there are at least 180 recognized species within this genus (Pitt et al. 2000), and the high frequency of Aspergillus in soil samples (Domsch et al. 1980), odds are low that any given Aspergillus species would be A. sydowii. Despite this, numerous authors continue to cite support for the hypothesis that African dust deposits are the source of this coral pathogen (Shinn et al. 2000, Garrison et al. 2003, Weir-Brush et al. 2004). The lack of identified A. sydowii in dust samples may reflect either the genuine absence of this microbe in African dust, or may be the result of insufficiently precise culture techniques. Growth media and temperature can strongly influence microbes cultured from environmental samples. In addition, culture-based techniques are themselves biased in that they only identify a subset of organisms (Barer et al. 1993). Given that the spores of Aspergillus are robust to temperature and UV stress (Abdalla 1988, Klich 2002a), specific methods should be used to investigate whether A. sydowii is transported to the Caribbean in wind-blown dust.

To determine whether African dust is a source of Aspergillus sydowii in Caribbean coral reefs, I identified fungi cultured from airborne dust collected in the Caribbean and Africa, and sediment samples from Africa and the Cape Verde Islands (in the eastern Atlantic). I used specific culture techniques to select for Aspergillus, and identified fungi within the genus to the species level.

\section{MATERIALS AND METHODS}

Airborne dust was collected from 2 locations (Table 1), viz. Emetteur Kati, Bamako, Mali $\left(12^{\circ} 41^{\prime} 17^{\prime \prime} \mathrm{N}\right.$, $\left.8^{\circ} 01^{\prime} 09^{\prime \prime} \mathrm{E}\right)$ at an elevation of $555 \mathrm{~m}$ during 3 dust events (March 2006), and Pt. Udall, St. Croix at an elevation of $40 \mathrm{~m}$ during a dust event (September 2006). In both locations, samples were taken using a portable vacuum filter sampling device described by Kellogg et al. (2004). Briefly, air was filtered through sterile cellulose nitrate membranes with a pore size of $0.2 \mu \mathrm{m}$, at a flow rate of $10 \mathrm{l} \mathrm{min}^{-1}$ for 10 to $12 \mathrm{~min}$. Following sampling, the filters were sealed, placed in Ziploc ${ }^{\mathrm{TM}}$ bags, and mailed to the USA. To account for potential contamination during handling, shipping, and processing of the filters, a control was included whereby the filtra- 
Table 1. Airborne dust sampling locations and conditions, mean fungal colony forming units per liter of air sampled (CFU $\left.{ }^{-1}\right)$ following $14 \mathrm{~d}$ of growth at $25^{\circ} \mathrm{C}$. SLPM: standard liter $\mathrm{min}^{-1}$

\begin{tabular}{|c|c|c|c|c|c|c|c|}
\hline Sampling location & Date & $\begin{array}{c}\text { Air temperature } \\
\left({ }^{\circ} \mathrm{C}\right)\end{array}$ & $\begin{array}{c}\text { Sampling } \\
\text { duration (min) }\end{array}$ & $\begin{array}{l}\text { Flow rate } \\
\text { (SLPM) }\end{array}$ & Dust event & $\begin{array}{l}\text { Wind speed } \\
\qquad\left(\mathrm{km} \mathrm{h}^{-1}\right)\end{array}$ & $\mathrm{CFU} \mathrm{I}^{-1}$ \\
\hline $\begin{array}{l}\text { Emetteur Kati, } \\
\text { Bamako, Mali }\end{array}$ & $23 / 3 / 2006$ & 38 & 10 & 12.5 & Yes & 12 & 0.076 \\
\hline $\begin{array}{l}\text { Emetteur Kati, } \\
\text { Bamako, Mali }\end{array}$ & $26 / 3 / 2006$ & 40 & 10 & 12.5 & Little dust & $1-15$ & 0.019 \\
\hline $\begin{array}{l}\text { Emetteur Kati, } \\
\text { Bamako, Mali }\end{array}$ & $28 / 3 / 2006$ & $>40$ & 10 & 12.25 & Smoke/dust & $5-10$ & 0.043 \\
\hline Pt. Udall, St. Croix & $17 / 9 / 2006$ & 40.5 & 12 & 17.5 & Yes & $18-25$ & 0.019 \\
\hline
\end{tabular}

tion apparatus was removed from its sterile packaging, but the cellulose membrane was not directly exposed to air. These samples were otherwise handled in an identical manner to the membranes that had air filtered across them.

Upon arrival in Ithaca, NY, USA the filters were cut in half with sterile scissors, and placed sample side up on malt extract agar (MEA) and dichloran-glycerol agar (DG18), both amended with $50 \mu \mathrm{g} \mathrm{ml}^{-1}$ tetracycline. These media were chosen specifically with the aim of culturing the coral pathogen Asperigillus sydowii. MEA is a commonly used medium for Aspergillus spp. (Klich 2002b), and best visualizes the diagnostic color of A. sydowii. DG18 is used to culture xerophilic fungi, such as Aspergillus spp. (Hocking \& Pitt 1980). Plates were incubated at $25^{\circ} \mathrm{C}$ for $14 \mathrm{~d}$. This incubation temperature is ideal for A. sydowii (Raper \& Fennell 1965), and is similar to that of previous fungal isolations from dust samples (Griffin et al. 2001b, Griffin et al. 2003, Kellogg et al. 2004, Weir-Brush et al. 2004). During the $14 \mathrm{~d}$ incubation period, all fungal colonies were counted and sub-cultured onto MEA daily.

Samples of surface sediment were taken in March 2006 from 1 site in Africa (Bamako, Mali), and 2 sites on Sal Island, in the Cape Verde Islands (Pedre de Lume and Punta Fiura). Samples were taken from the top $0.5 \mathrm{~cm}$ of sediment over a surface area of approximately $55 \mathrm{~cm}^{2}$, and were collected and packaged using sterile technique. Upon arrival in the USA, the sediment was serially diluted $\left(10^{-2}, 10^{-3}, 10^{-4}, 10^{-5}\right)$ and plated onto both MEA and DG18 amended with tetracycline. Plates were incubated at $25^{\circ} \mathrm{C}$ for $14 \mathrm{~d}$. All fungal colonies were counted and sub-cultured daily.

Fungi were identified to genus using Domsch et al. (1980) and St. Germain \& Summerbell (1996). All Aspergillus spp. were identified to species according to Klich (2002b); colony-level morphological characteristics (color, growth rate) and microscopic characteristics (standard 100× light microscopy for shape and color of conidia, sporulating structures (vesicles) and hyphae) were examined. Species identification is based on characteristic morphologies when the fungus is grown on 3 diagnostic media (Czapek yeast extract agar, Czapek yeast extract agar with $20 \%$ sucrose, and malt extract agar) at 2 temperatures $\left(25^{\circ} \mathrm{C}, 37^{\circ} \mathrm{C}\right)$. All fungi were preserved in both $70 \%$ ethanol and phosphate buffered saline with $10 \%$ glycerol, and stored at $-80^{\circ} \mathrm{C}$. The number of fungal colony forming units per liter of air sampled ( $\mathrm{CFU} \mathrm{l}^{-1}$ ) are reported for airborne dust, and the number of fungal colony forming units (CFU) are reported for sediment samples.

\section{RESULTS}

Both culturing media (DG18 and MEA) were effective in isolating a diversity of fungi from the airborne dust samples (Table 2). After 2 wk of growth, the number of fungi in the samples from Mali ranged from 0 to $0.104 \mathrm{CFU} \mathrm{l}^{-1}$, and those from St. Croix ranged from 0.005 to $0.033 \mathrm{CFU} \mathrm{l}^{-1}$ (Table 2). Overall, samples from Mali had higher fungal abundances than those from St. Croix, although the 3 sampling dates in Mali were quite variable. Fungal abundance appears to be related to the magnitude of the dust event; the highest fungal counts were obtained during obvious dust events (Mali, 23 March), and the lowest when little dust was in the air (Mali, 26 March). No fungus grew in the handling controls, indicating that the manipulation, shipping, and storage of samples was effective in preventing contamination.

The most common fungal genus in airborne dust samples from Mali was Cladosporium, comprising $35.5 \%$ of all colonies (Table 2). In St. Croix, the most common fungal genus was Acremonium. Seven species of Aspergillus (including Emericella sp. and Eurotium sp., sexual stages of Aspergillus spp.) were observed overall, and ranged from 3 to $15 \%$ of the total colonies (Table 2). Airborne dust from Mali contained all 7 Aspergillus species, and dust from St. Croix contained only A. niger. None of the recorded Aspergillus colonies was A. sydowii. Although Aspergillus can be a taxonomically challenging genus, I have high confi- 
Table 2. Fungal species isolated from airborne dust collected in Mali and St. Croix. Abundance is the proportion of colony forming units (CFUs) on both types of culturing media (DG18 and MEA) for all replicate filters following $14 \mathrm{~d}$ of growth at $25^{\circ} \mathrm{C}$

\begin{tabular}{|lcccc|}
\hline \multirow{2}{*}{ Fungal species } & \multicolumn{4}{c|}{ Abundance (\% total CFU) } \\
\cline { 2 - 5 } & 23 March & 26 March & 28 March & 17 Sept \\
\cline { 2 - 5 } & & & & \\
\hline Cladosporium spp. & 49.1 & 0 & 28.1 & 6.3 \\
Yeast & 6.8 & 62.5 & 0 & 9.4 \\
All Aspergillus spp. & 10.2 & 6.3 & 15.6 & 3.1 \\
A. fumigatus & 0 & 0 & 3.1 & 0 \\
A. niger & 3.4 & 0 & 6.3 & 3.1 \\
A. niveus & 0 & 6.3 & 0 & 0 \\
A. sydowii & 0 & 0 & 0 & 0 \\
A. terreus & 3.4 & 0 & 0 & 0 \\
A. ustus & 0 & 0 & 3.1 & 0 \\
Eurotium sp. & 1.7 & 0 & 0 & 0 \\
Emericella sp. & 0 & 0 & 3.1 & 0 \\
Penicillium spp. & 1.7 & 0 & 3.1 & 3.1 \\
Curvularia spp. & 1.7 & 0 & 6.3 & 0 \\
Acremonium spp. & 0 & 0 & 3.1 & 15.6 \\
Fusarium spp. & 0 & 0 & 0 & 9.4 \\
Stachybotrys sp. & 0 & 6.3 & 0 & 0 \\
Paecilomyces sp. & 0 & 0 & 0 & 3.1 \\
Sporothrix sp. & 0 & 0 & 0 & 3.1 \\
Nigrosporium sp. & 0 & 0 & 0 & 3.1 \\
Unidentified & 30.5 & 25 & 43.8 & 43.8 \\
filamentous fungi & & & & \\
\hline & & & & \\
\hline
\end{tabular}

dence in the species identifications as I used an established set of morphological characters based on growth on 3 types of diagnostic media at 2 temperatures (Klich $2002 \mathrm{~b}$ ). Of the species observed, none was easily confused with $A$. sydowii, which has a characteristic turquoise colony color, relatively slow colony growth rates, and rough-walled conidia (Klich 2002b).

Table 3. Fungal species from sediment samples collected in Mali (26 March 2006) and Cape Verde (16 March 2006). Abundance is the number of colonyforming units (CFUs) averaged over both types of culturing media (DG18 and MEA) for all replicate filters following $48 \mathrm{~h}$ of growth at $25^{\circ} \mathrm{C}$

\begin{tabular}{|c|c|c|c|}
\hline \multirow{3}{*}{$\begin{array}{l}\text { Sediment } \\
\text { dilution }\end{array}$} & \multirow{3}{*}{$\begin{array}{c}\text { Mali } \\
\text { Bamako }\end{array}$} & Abundance (CFU) & \\
\hline & & \multirow{2}{*}{$\overline{\text { Pedra de Lume }}^{\text {Cap }}$} & Verde \\
\hline & & & Punta Fiura \\
\hline \multirow{5}{*}{$\begin{array}{l}10^{-2} \\
10^{-3} \\
10^{-4} \\
10^{-5}\end{array}$} & 58.5 & 25.5 & 5.5 \\
\hline & 30 & 7.5 & 0 \\
\hline & 9 & 1 & 0 \\
\hline & 4.5 & Overgrown & 0 \\
\hline & Bamako & $\begin{array}{l}\text { Common fungal species } \\
\text { Pedra de Lume }\end{array}$ & Punta Fiura \\
\hline & $\begin{array}{l}\text { Aspergillus niger, } \\
\text { Cladosporium spp., } \\
\text { zygomycete, } \\
\text { enicillium spp., yeast }\end{array}$ & $\begin{array}{l}\text { Cladosporium spp., } \\
\text { Aspergillus ustus, } \\
\text { A. terreus, yeast, } \\
\text { zygomycete }\end{array}$ & Cladosporium spp. \\
\hline
\end{tabular}

Sediment samples had much higher fungal abundances than air samples, and a dilution of at least $10^{-4}$ was necessary to prevent complete overgrowth within $48 \mathrm{~h}$ (Table 3). Samples from one of the sites on Cape Verde (Punta Fiura) had low abundance of fungi; dilutions greater than $10^{-3}$ showed no growth. Overall, it was difficult to assess fungal diversity in the sediment samples due to the high density of colonies. Species observed were similar to those in the airborne dust samples (Cladosporium, Penicillium, yeast, Aspergillus spp.). Three species of Aspergillus were observed ( $A$. niger, A. terreus, A. ustus), but A. sydowii was not among them (Table 3).

\section{DISCUSSION}

No evidence of the coral pathogen Aspergillus sydowii was found in 3 airborne dust samples from Africa and 1 from the Caribbean, or in sediment samples from Africa and the Cape Verde Islands (Tables 2 \& 3). Our targeted approach using culturing media selective for the growth of Aspergillus (MEA and DG18) and detailed identification methods (Klich 2002 b) was successful, yielding 7 different species of Aspergillus and related taxa. The most common taxon was Cladosporium spp., which agrees with Lacey's (1991) observation that this is the most abundant fungus in temperate and tropical air samples.

A comparison of these results with previous examinations of the fungal biota from African dust revealed some interesting trends (Table 4). The abundance of fungi in Mali air samples from this study were lower than those collected in 2001 and 2002 in the same region (Kellogg et al. 2004). This could be the result of factors such as large-scale climate patterns (i.e. North Atlantic Oscillation) or local conditions (humidity, UV, temperature, aerosol concentrations). Temporal variation in microbial abundance in air samples is well documented, and is related to the concentration of dust in the air, which varies seasonally, with maximum deposition in June/July, and inter-annually, with deposition strongly tied to low rainfall in Africa and largescale climate processes (Nickling \& Gillies 1993, Fontaine \& Janicot 1996, Tegen et al. 1996).

From an examination of previous studies, it was not possible for me to assess the role of different culture techniques on fungal abundance, as this was confounded with both sampling location and time (Table 4). However, 
Table 4. Comparison of methodology and results of this and previous studies examining the fungal biota of African dust. Only samples taken during documented dust events are included. CFU $1^{-1}$ : colony forming units per unit of filtered air. Y: yes, N: no, USVI: US Virgin Islands

\begin{tabular}{|c|c|c|c|c|c|c|c|c|}
\hline \multicolumn{2}{|c|}{ Sampling } & \multirow[t]{2}{*}{ Media } & \multicolumn{2}{|c|}{ Incubation- } & \multirow[t]{2}{*}{$\mathrm{CFU} \mathrm{I}^{-1}$} & \multicolumn{2}{|c|}{ Presence of } & \multirow[t]{2}{*}{ Source $^{a}$} \\
\hline Location & Date & & Temp. $\left({ }^{\circ} \mathrm{C}\right)$ & Time & & Aspergillus & A. sydowii & \\
\hline St. John & Jul 2000 & R2A & Room & $2 \mathrm{wk}$ & 0.048 & $\mathrm{~N}$ & $\mathrm{~N}$ & 1 \\
\hline USVI & Jul 2001 & $\mathrm{R} 2 \mathrm{~A}$ & 23 & $48 \mathrm{~h}$ & 0.024 & $\mathrm{~N}$ & $\mathrm{~N}$ & 2 \\
\hline USVI & Aug 2001 & $\mathrm{R} 2 \mathrm{~A}$ & 23 & $48 \mathrm{~h}$ & 0.065 & $\mathrm{Y}$ & Unknown (to genus) & 2 \\
\hline USVI & Jul 1999 & YEG, MEG & 28 & Unknown & - & $\mathrm{Y}$ & Unknown (to genus) & 3 \\
\hline USVI & Sept 1999 & $\mathrm{YEG}, \mathrm{MEG}$ & 28 & Unknown & - & $\mathrm{Y}$ & Unknown (to genus) & 3 \\
\hline Mali & 2001,2002 & R2A & 26 & $48 \mathrm{~h}$ & 0.225 & $\mathrm{Y}$ & Unknown (to genus) & 4 \\
\hline Barbados & Apr 1996 & Sabouraud & $\begin{array}{l}37 \text { for } 48 \mathrm{~h}, \\
30 \text { for } 2 \mathrm{wk}\end{array}$ & $2 \mathrm{wk}$ & 0.003 & - & - & 5 \\
\hline Barbados & Jun 1997 & Sabouraud & $\begin{array}{l}37 \text { for } 48 \mathrm{~h}, \\
30 \text { for } 2 \mathrm{wk}\end{array}$ & $2 \mathrm{wk}$ & 0.015 & - & - & 5 \\
\hline Mali & Mar 2006 & MEA, DG18 & 25 & $2 \mathrm{wk}$ & 0.035 & $\mathrm{Y}$ & $\mathrm{N}$ & 6 \\
\hline St. Croix & Sept 2006 & MEA, DG18 & 25 & $2 \mathrm{wk}$ & 0.015 & $\mathrm{Y}$ & $\mathrm{N}$ & 6 \\
\hline
\end{tabular}

several authors found no significant difference in CFUs using nutrient-rich (i.e. Sabouraud) and nutrient-poor (i.e. R2A) media (Kellogg et al. 2004, Prospero et al. 2005). I also found little difference in either fungal abundance or diversity between the 2 types of culturing media used (DG18 and MEA). Some of the lowest fungal abundances observed were from Barbados (Prospero et al. 2005) in a study that used the highest incubation temperature $\left(30^{\circ} \mathrm{C}\right)$. This might be the result of either the temperature under which fungi were grown, or geographic variation.

Several previous studies have documented the presence of Aspergillus spp. in African dust (Griffin et al. 2003, Kellogg et al. 2004, Weir-Brush et al. 2004). However, none of these identified fungi to the species level. Methods of identifying fungi from dust samples include morphology (Weir-Brush et al. 2004) and 16S/18S rDNA sequencing (Griffin et al. 2001b, Griffin et al. 2003, Kellogg et al. 2004). The presence of Aspergillus spp. in samples does not necessarily indicate that the coral pathogen $A$. sydowii is present; this is a diverse fungal genus and species identification can be difficult. For example, $A$. versicolor, which is a morphologically similar close relative of $A$. sydowii, is extremely widespread in soil and air samples (Domsch et al. 1980, Klich 2002a, Gorbushina et al. 2007). I used detailed morphological analysis of fungi based on growth on 3 types of diagnostic media at 2 temperatures (Klich 2002b) to confirm the identity of all Aspergillus species. This method has high precision at the species level, in contrast to $16 \mathrm{~S} / 18 \mathrm{~S}$ rDNA sequencing used by previous studies that can only identify fungi to genus. Recently developed speciesspecific molecular probes (Haughland et al. 2004) may provide an alternate approach to identifying fungi at higher taxonomic resolution in dust samples. Regardless of the method, if the goal is to identify specific fungi (such as the coral pathogen $A$. sydowii), more detailed analyses of the morphological and molecular traits are required to assign species identity.

It is important to realize that the presence of viable fungus in African dust samples does not necessarily indicate that it is capable of infecting coral hosts. Likewise, studies such as mine may overlook non-culturable isolates of fungus. The environmental conditions a fungus encounters prior to infecting a coral host are not easily duplicated in the laboratory, and therefore it is possible that not all fungi capable of infecting hosts are cultured using traditional methods. However, given the resilience of fungal spores to the harsh conditions found in dust clouds, and the optimal nutrient and temperature conditions of the culturing media, it seems likely that most viable spores would germinate. Whether these spores are capable of infecting coral hosts requires further study.

A lack of Aspergillus sydowii in dust samples from both Africa and the Caribbean in this study makes it tempting to conclude that African dust is not a viable source of this coral pathogen. However, given the large spatial and temporal variation in fungal diversity and abundance, I cannot conclusively rule out the African Dust hypothesis, or the possibility that $A$. sydowii was present in dust from earlier years. Comparisons with previous studies emphasize that inputs from African dust into marine systems are likely to be spatially and temporally variable, and specific culturing and identification methods must be used to conclusively determine the presence of A. sydowii in African dust. Future tests of the African Dust hypothesis are important and should use targeted searches with potential pathogens identified to as fine a taxonomic 
resolution as possible. It is not sufficient to identify to the genus level, as aspergillosis of corals is caused by a single species. Aspergillus is a diverse genus, and the evidence of several other species of Aspergillus within our dust samples suggests that taxonomic resolution to the species-level is necessary.

Ackowledgements. Thanks to G. Garrison (USGS), and M. Peterson (University of the Virgin Islands) for dust sample collection, and to M. Klich (USGS) for assistance in species identification. This work was funded by NSF grants to C. D. Harvell (EID OCE-0326705 and OCE-9818830) and a Teresa Heinz Scholar for Environmental Research grant (K.L.R). Fungal isolates were transported and maintained according to USDA permit P526P-06-00465.

\section{LITERATURE CITED}

Abdalla MH (1988) Prevalence of airborne Aspergillus flavus in Khartoum (Sudan) airspora with reference to dusty weather and inoculum survival in simulated summer conditions. Mycopathologia 104:137-141

Arimoto R, Duce RA, Ray BJ, Tomza U (2003) Dry deposition of trace elements to the western North Atlantic. Global Biogeochem Cycles 17:1010

Aylor DE (2003) Spread of plant disease on a continental scale: role of aerial dispersal of pathogens. Ecology 84:1989-1997

Barer MR, Gribbon LT, Harwood CR, Nwoguh CE (1993) The viable but non-culturable hypothesis and medical bacteriology. Rev Med Microbiol 4:183-191

Brown JKM, Hovmoller MS (2002) Aerial dispersal of pathogens on the global and continental scales and its impact on plant disease. Science 297:537-541

D'Almeida GA (1986) A model for Saharan dust transport. J Clim Appl Meteorol 25:903-916

Domsch KH, Gams W, Anderson TH (1980) Compendium of soil fungi. Academic Press, London

Erel Y, Dayan U, Rabi R, Rudich Y, Stein M (2006) Transboundary transport of pollutants by atmospheric mineral dust. Environ Sci Technol 40:2996-3005

Fabricius KE (2005) Effects of terrestrial runoff on the ecology of corals and coral reefs: review and synthesis. Mar Pollut Bull 50:125-146

Fontaine B, Janicot S (1996) Sea surface temperature fields associated with West African rainfall anomaly types. J Climatol 9:2935-2940

Garrison VH, Shinn EA, Foreman WT, Griffin DW and others (2003) African and Asian dust: from desert soils to coral reefs. Bioscience 53:469-480

Garrison VH, Foreman WT, Genualdi S, Griffin DW and others (2006) Saharan dust - a carrier of persistent organic pollutants, metals and microbes to the Caribbean? Rev Biol Trop 54:9-21

Garzón-Ferreira J, Zea S (1992) A mass mortality of Gorgonia ventalina (Cnidaria: Gorgoniidae) in the Santa Marta area, Caribbean coast of Columbia. Bull Mar Sci 50:522-526

Geiser DM, Taylor JW, Ritchie KB, Smith GW (1998) Cause of sea fan death in the West Indies. Nature 394:137-138

Giannini A, Saravanan R, Chang P (2003) Oceanic forcing of Sahel rainfall on interannual to interdecadal time scales. Science 302:1027-1030
Gorbushina AA, Kort R, Schulte A, Lazarus D and others (2007) Life in Darwin's dust: intercontinental transport and survival of microbes in the nineteenth century. Environ Microbiol 9:2911-2922

Griffin DW, Kellogg CA, Shinn EA (2001a) Dust in the wind: long range transport of dust in the atmosphere and its implications for global public and ecosystem health. Glob Change Hum Health 2:20-34

- Griffin DW, Garrison VH, Herman JR, Shinn EA (2001b) African desert dust in the Caribbean atmosphere: microbiology and public health. Aerobiologia 17:203-213

Griffin DW, Kellogg CA, Garrison VH, Lisle JT, Borden TC, Shinn EA (2003) Atmospheric microbiology in the northern Caribbean during African dust events. Aerobiologia 19:143-157

> Harvell CD, Kim K, Burkholder JM, Colwell RR and others (1999) Emerging marine diseases: climate links and anthropogenic factors. Science 285:1505-1510

> Harvell CD, Mitchell CE, Ward JR, Altizer S, Dobson AP, Ostfeld RS, Samuel MD (2002) Climate warming and disease risks for terrestrial and marine biota. Science 296: $2158-2162$

Harvell D, Jordán-Dahlgren E, Merkel S, Rosenberg E and others (2007) Coral disease, environmental drivers, and the balance between coral and microbial associates. Oceanography 20:172-195

Haugland RA, Varma M, Wymer LJ, Vesper SJ (2004) Quantitative PCR analysis of selected Aspergillus, Penicillium and Paecilomyces species. Syst Appl Microbiol 27:198-210

- Hayes ML, Bonaventura J, Mitchell TP, Prospero JM, Shinn EA, Van Dolah F, Barber RT (2001) How are climate and marine biological outbreaks functionally linked? Hydrobiologia 460:213-220

> Herman JR, Krotkov N, Celarier E, Larko D, Labow G (1999) Distribution of UV radiation at the Earth's surface from TOMS-measured UV-backscattered radiances. J Geophys Res 104:12059-12076

> Hocking AD, Pitt JI (1980) Dichloran-glycerol medium for enumeration of xerophilic fungi from low-moisture foods. Appl Environ Microbiol 39:488-492

$>$ Hoegh-Guldberg O (1999) Climate change, coral bleaching and the future of the world's coral reefs. Mar Freshw Res 50:839-866

Hughes TP (1994) Catastrophes, phase shifts, and large-scale degradation of a Caribbean coral reef. Science 265: $1547-1551$

Jickells TD, An ZS, Andersen KK, Baker AR and others (2005) Global iron connections between desert dust, ocean biogeochemistry, and climate. Science 308:67-71

Kellogg CA, Griffin DW, Garrison VH, Peak KK, Royall N, Smith RR, Shinn EA (2004) Characterization of aerosolized bacteria and fungi from desert dust events in Mali, West Africa. Aerobiologia 20:99-110

> Kim K, Harvell CD (2004) The rise and fall of a six-year coralfungal epizootic. Am Nat 164:S52-S63

Klich MA (2002a) Biogeography of Aspergillus species in soil and litter. Mycologia 94:21-27

Klich MA (2002b) Identification of common Aspergillus species. Centraalbureau voor Schimmelcultures, Utrecht

Lacey J (1991) Aerobiology and health: The role of airborne fungal spores in respiratory disease. In: Hawksworth DL (ed) Frontiers in mycology. C.A.B. International, Farnham, p 157-186

Moulin C, Chiapello I (2006) Impact of human-induced desertification on the intensification of Sahel dust emission and export over the last decades. Geophys Res Lett 33, L18808 
Moulin C, Lambert CE, Dulac F, Dayan U (1997) Control of atmospheric export of dust from North Africa by the North Atlantic Oscillation. Nature 387:691-694

Nagelkerken I, Buchan K, Smith GW, Bonair K and others (1997) Widespread disease in Caribbean sea fans: II. Patterns of infection and tissue loss. Mar Ecol Prog Ser 160: 255-263

Nickling WG, Gillies JA (1993) Dust emission and transport in Mali, West Africa. Sedimentology 40:859-868

Pitt JI, Samson RA, Frisvad JC (2000) List of accepted species and their synonyms in the family Trichocomaceae. In: Samson RA, Pitt JI (eds) Integration of modern taxonomic methods for Penicillium and Aspergillus classification. Harwood Academic Publishers, Reading, p 9-49

Prospero JM (1968) Atmospheric dust studies on Barbados. Bull Am Meteorol Soc 49:645-652

Prospero JM, Lamb PJ (2003) African droughts and dust transport to the Caribbean: climate change implications. Science 302:1024-1027

Prospero JM, Nees RT (1986) Impact of the North African drought and El Niño on mineral dust in the Barbados trade winds. Nature 320:735-738

Prospero JM, Bonatti E, Schubert C, Carlson TN (1970) Dust in the Caribbean atmosphere traced to an African dust storm. Earth Planet Sci Lett 9:287-293

Prospero JM, Barrett K, Church T, Dentener F and others (1996) Atmospheric deposition of nutrients to the North Atlantic Basin. Biogeochemistry 35:27-73

Prospero JM, Blades E, Mathison G, Naidu R (2005) Interhemispheric transport of viable fungi and bacteria from Africa to the Caribbean with soil dust. Aerobiologia 21:1-19

Raper KB, Fennell DI (1965) The genus Aspergillus. The Williams \& Wilkins Company, Baltimore, MD

Editorial responsibility: Tim McClanahan, Mombasa, Kenya
Roth FJ Jr, Orpurt PA, Ahearn DG (1964) Occurrence and distribution of fungi in a subtropical marine environment. Can J Bot 42:375-383

Shinn EA, Smith GW, Prospero JM, Betzer P, Hayes ML, Garrison V, Barber RT (2000) African dust and the demise of Caribbean coral reefs. Geophys Res Lett 27: 3029-3032

Shinn EA, Griffin DW, Seba DB (2003) Atmospheric transport of mold spores in clouds of desert dust. Arch Environ Health 58:498-504

Smith GW, Ives LD, Nagelkerken IA, Ritchie KB (1996) Caribbean sea-fan mortalities. Nature 383:487

St. Germain G, Summerbell R (1996) Identifying filamentous fungi: a clinical laboratory handbook. Star Publishing, Belmont, CA

Steele CW (1967) Fungus populations in marine waters and coastal sands of Hawaiian, Line, and Phoenix Islands. Pac Sci 21:317-331

Tegen I, Lacis AA, Fung I (1996) The influence on climate forcing of mineral aerosols from disturbed soils. Nature 380:419-422

> van Dijk HFG, Guicherit R (1999) Atmospheric dispersion of current-use pesticides: a review of the evidence from monitoring studies. Water Air Soil Pollut 115:21-70

> Venkatesh MV, Joshi K, Harjai S, Ramdeo I (1975) Aspergillosis in desert locust (Schistocerca gregaria Forsk). Mycopathologia 57:135-138

Ward JR, Lafferty KD (2004) The elusive baseline of marine disease: are diseases in ocean ecosystems increasing? PLoS Biol 2:542-547

Weir-Brush JR, Garrison VH, Smith GW, Shinn EA (2004) The relationship between gorgonian coral (Cnidaria: Gorgonacea) diseases and African dust storms. Aerobiologia 20:119-126

Submitted: April 18, 2008; Accepted: June 5, 2008 Proofs received from author(s): September 3, 2008 